\title{
IDENTIDADE EM TRANSIÇÃO: \\ CABO VERDE E A TAÇA AMÍLCAR CABRAL
}

Victor Andrade de Melo*
Rafael Fortes**

$\mathrm{E}$

m Cabo Verde, colônia de Portugal até 1975, em função de uma série de particularidades históricas, percebe-se, desde o século XVIII, a conformação de uma elite local, constituída por mestiços. Nesse quadro, notadamente a partir do quartel final do século XIX, a adesão a certas práticas integrava o conjunto de iniciativas que visava a subverter a consideração, por parte do colonizador, de que o nativo era "alguém menor": demonstrando ser civilizado, podia exigir um tratamento diferenciado. Em certa medida, essa condição era reconhecida pela própria metrópole, que concedia ao arquipélago certas exceções no relacionamento colonial. ${ }^{1}$

Demonstrar hábitos modernos, entre os quais o envolvimento com as práticas esportivas, reforçava a ideia tão mobilizada pelas lideranças locais de que Cabo Verde era uma colônia distinta. De fato, o esporte ocupou um lugar de grande importância na história do arquipélago, inclusive dramatizando as tensões de suas construções identitárias, tanto no que se refere aos debates entre as duas principais cidades e ilhas, Mindelo/São Vicente e Praia/Santiago, quanto no que tange à relação com o colonizador. ${ }^{2}$

Professor da UFRJ. victor.a.melo@uol.com.br.

** Professor da Unirio.raffortes@hotmail.com.

1 Gabriel Fernandes, Em busca da nação: notas para uma reinterpretação do Cabo Verde crioulo, Florianópolis/Praia: Editora da UFSC/Instituto da Biblioteca Nacional e do Livro, 2006.

2 Victor Andrade de Melo, Jogos de identidade: o esporte em Cabo Verde, Rio de Janeiro: Apicuri/ CNPq, 2011. 
A partir de 1975, quando a colônia se tornou independente e adotou um regime de governo de partido único de viés socialista, o Partido Africano para Independência da Guiné e de Cabo Verde (PAIGC), ${ }^{3}$ concebeu-se uma visão de esporte embasada em uma crítica a antigas tradições esportivas do arquipélago, encaradas como manifestação de um colonialismo que deveria ser extirpado. ${ }^{4}$

$\mathrm{Na}$ mesma medida, o partido único tentou engajar a prática esportiva nos seus propósitos de "africanizar os espíritos", algo que ia de encontro à linha majoritária de construção identitária cabo-verdiana, que apresentava a mestiçagem como o grande diferencial do arquipélago. $\mathrm{O}$ intuito central do PAIGC, enfim, era que o esporte expressasse e ajudasse a forjar o "novo homem cabo-verdiano". 5

Tal linha de intervenção enfrentou muitas resistências e teve de lidar com uma ambiguidade central: como coadunar a ideia de massificação com o desejo de obtenção de notáveis resultados internacionais? O bom desempenho das equipes nacionais interessava tanto aos envolvidos com o campo esportivo quanto aos dirigentes governamentais, ávidos por ver o país reconhecido no cenário africano e por legitimar suas propostas no quadro interno.

Isso não era uma estratégia incomum: o esporte foi e continua sendo utilizado por regimes políticos e administrações governamentais, tanto como estratégia para encaminhar propostas de intervenção social, quanto como propaganda de uma suposta eficácia administrativa, para alguns um reflexo dos "avanços do país". ${ }^{6}$ Por essas dimensões, muitos

O PAIGC esteve à frente do governo entre os anos de 1975 e 1991. Para mais informações sobre o processo de independência de Cabo Verde, ver: José Vicente Lopes, Cabo Verde: os bastidores da independência, Praia: Spleen, 2002; e Aristides Pereira, O meu testemunho - uma luta, um partido, dois países, Lisboa: Editorial Notícias, 2003.

4 Melo, Jogos de identidade.

5 Melo, Jogos de identidade. A ideia de forjar um "novo homem" foi comum em muitos países que adotaram o socialismo, algo que estava presente, com diferentes enfoques, no pensamento de importantes líderes como Stalin, Lenin, Mao Tse Tung, Che Guevara, Fanon, Paulo Freire e Amílcar Cabral, entre outros.

6 Para uma discussão sobre as relações entre esporte e governos no continente africano, ver: Richard Giulianotti, "Os estudos do esporte no continente africano", in Victor Andrade de Melo, Marcelo Bittencourt e Augusto Nascimento (orgs.), Mais do que um jogo: o esporte no continente africano (Rio de Janeiro: Apicuri, 2010), pp.5-35. 
autores já argumentaram que há uma forte relação entre a prática esportiva e a construção de discursos acerca de uma identidade nacional. ${ }^{7}$

Em muitos países africanos, o esporte desempenhou um papel significativo na constituição da ideia de nação, porque, em função da condição colonial, havia no continente, em geral, menos elementos a serem mobilizados para a construção de um sentido de nacionalidade, algo que se acirrava com a frequente existência de várias etnias no cenário de cada país. Nesse sentido, parece interessante o olhar de Hobsbawm: "a existência da seleção nacional de futebol estabeleceu, em alguns casos pela primeira vez, uma identidade nacional independente das identidades locais, tribais ou religiosas". 8

O esporte providenciava aos países recém-independentes tanto elementos discursivos exógenos (reconhecimento internacional por um meio não "oficial", mas altamente visível) quanto endógenos:

Em meio a todas as mudanças constitucionais, golpes militares e guerras civis, jovens nações africanas adaptam velhos estilos europeus de governo para atender suas próprias necessidades. Para fins de saúde e disciplina, eles também promoveram jogos atléticos ocidentais e programas de educação física em suas escolas. Eles elegeram o esporte para ser um denominador comum de valor incalculável para reunir várias tribos com diferentes costumes e línguas em uma única nação. ${ }^{9}$

No caso de Cabo Verde, essa mobilização tornou-se mais notável a partir de 1977, quando começaram a ser percebidas mudanças nas propostas políticas originais do PAIGC, algo que será acentuado, em 1980, com a crise na Guiné-Bissau, um golpe de estado que acabou por dar fim ao projeto de construção de um Estado único binacional entre os dois países. ${ }^{10}$

Richard Giulianotti, Sport: a Critical Sociology, Cambridge: Polity Press, 2005.

8 Eric Hobsbawm, Globalização, democracia e terrorismo, São Paulo: Companhia das Letras, 2007, p.95.

9 William J. Baker, "Political Games: the Meaning of International Sport for Independent Africa", in William J. Baker e James A. Mangan (eds.), Sport in Africa: Essays in Social History (Nova York: African Publishing Company, 1987), p.277.

10 Como as lutas coloniais contra Portugal foram conduzidas em conjunto por militantes da Guiné e de Cabo Verde, construiu-se, com a independência, a ideia de se forjar um Estado único binacional. As fraturas nunca foram, porém, totalmente sanadas, tendo, inclusive, sido responsáveis pela morte de Amílcar Cabral. Quando houve um golpe de estado que depôs o primeiro presidente da Guiné-Bissau independente, Luís Cabral, irmão de Amílcar, o projeto original foi definitivamente sepultado. Para mais informações, ver: Lopes, Cabo Verde; e Pereira, O meu testemunho. 
Paulatinamente, promoveu-se um retorno a algumas ideias do passado, relidas a partir da dinâmica de um país independente.

Um dos impactos desse processo na política esportiva foi a busca de maior inserção do país no cenário internacional. Essa intenção, contudo, era, a princípio, cercada de polêmicas, já que permanecia a crítica a uma visão de esporte tida como colonial. Assim se posicionava o Voz di Povo: "O que se quer acentuar é que torna-se necessário revolucionar a mentalidade desportiva atual que faz o culto do vencedor, cria mitos, impõe a vitória a qualquer preço e é um eterna fonte de conflitos". ${ }^{11} \mathrm{O}$ momento era marcado por ressalvas e ambiguidades:

Com a independência de nosso país aumentaram-se as possibilidades de participação em encontros desportivos internacionais e a compreensão dessa participação deve ser encaminhada num plano puramente desportivo (nem derrotas honrosas, nem vitórias retumbantes), mas sim um encontro de homens que praticam desporto. Qualquer outra veleidade e desvio implicarão frustrações, euforias que em nada contribuirão para a formação do homem novo cabo-verdiano, livre de complexos e desalienado. ${ }^{12}$

Na ocasião, estava por vir a estreia do país em competições internacionais. Anunciava-se, para o ano de 1979, a realização da primeira edição da Taça Amílcar Cabral, a ser disputada entre seleções de futebol de países da chamada Zona 2 do Conselho Superior do Desporto da África: ${ }^{13}$ Cabo Verde, Gâmbia, Guiné Conacri, Guiné-Bissau, Mali, Mauritânia, Senegal e Serra Leoa. O intuito maior anunciado era celebrar a união africana por meio de uma homenagem ao líder que tanta importância teve para a história de libertação do continente.

Sobre essa edição da taça, há um interessante curta/documentário: Torneio Amilcar Cabral (1979). ${ }^{14}$ As primeiras cenas exibem as bandeiras dos países participantes e flashs da cerimônia de abertura: delegações, autoridades, arquibancadas lotadas. Além de imagens dos jogos, perce-

11 Voz di Povo, ano 3, n.132, 18/02/1978, p.6.

12 Voz di Povo, ano 3, n.132, 18/02/1978, p.6.

13 O Conselho foi criado, em 1966, para coordenar as ações esportivas no âmbito do pan-africanismo e reconhecido, em 1967, pela Organização da Unidade Africana.

14 Dirigido por Fernando Cabral, Jom Tob Azulay e Flora Gomes; uma produção conjunta Brasil-Guiné. 
be-se a constante busca de vinculação da competição com a memória de Amílcar Cabral, tanto nas falas dos dirigentes quanto nos depoimentos do público, assim como nas homenagens realizadas: o evento é apresentado como grande ode ao "pai da nacionalidade".

A ideia de promover com frequência a Taça Amílcar Cabral parece ter surgido de dirigentes da Guiné-Bissau, que, inclusive, já tinham organizado um torneio amistoso, com o mesmo nome, com cinco países, em junho de 1975. Não há indícios da participação de Cabo Verde nessa ocasião, algo compreensível, pois o país estava envolto com os preparativos da sua independência. ${ }^{15}$

Tendo em conta que é usual a mobilização da prática esportiva na construção de discursos identitários, este estudo tem por objetivo discutir as representações da imprensa de Cabo Verde sobre a participação do selecionado nacional de futebol na Taça Amílcar Cabral. Sugerimos que as diferentes posições sobre o envolvimento do país com esse torneio permitem perceber as mudanças em curso na administração governamental, relacionadas, inclusive, com os trânsitos e as negociações ligadas à identidade cabo-verdiana.

Trabalhou-se com o Voz di Povo, periódico dirigido pelo partido único que governava o país, lançado em 17 de julho de 1975, no mesmo dia em que tomou posse o primeiro governo do Cabo Verde independente. Publicado semanal, quinzenal ou mensalmente, dependendo das condições econômicas do momento, mesmo se tratando de um órgão oficial, nas páginas desse jornal não eram publicados somente posicionamentos que interessavam às lideranças, sendo possível também captar os conflitos e os debates que marcavam a nação em formação. ${ }^{16}$

\section{Taça Amílcar Cabral: a estreia da nação}

Todos nós sabemos as dificuldades que se nos deparam para formar uma seleção que seja representativa do valor real do futebol cabo-verdiano. A descontinuidade

15 A cerimônia de independência de Cabo Verde foi realizada em 5 de julho de 1975. A GuinéBissau já era independente desde 24 de setembro de 1973, a data unilateralmente estabelecida pelo PAIGC, ou desde 10 de setembro de 1974, a data de reconhecimento por parte de Portugal.

16 Na ocasião, existia outro jornal sendo publicado, Terra Nova, de propriedade da Igreja Católica, mas optou-se por trabalhar, neste artigo, somente com os posicionamentos e debates veiculados no Voz di Povo. 
do território não permite uma apreciação global dos atletas não só por escassez de contactos inter-ilhas, mas também por inexistência de um selecionador permanente.

Mas também é verdade que esta participação cabo-verdiana deve ser encarada, principalmente como um contato necessário para o desenvolvimento do nosso desporto. É preciso acabar com este isolacionismo a que fomos votados durante os anos de dominação colonial e que tão prejudicial foi ao nosso desporto. ${ }^{17}$

Essa avaliação do jornalista do Voz di Povo integrava uma matéria que saudava a primeira vez que um selecionado oficial cabo-verdiano de futebol representaria o país, tomando parte em um quadrangular promovido com as equipes nacionais de Mali, Guiné Conacri e Guiné-Bissau, a ser realizado neste último país, em 1978.

Há na matéria duas chaves de argumentação que serão muito comuns no decorrer do tempo: a) a ideia de que o cabo-verdiano tem predisposição "quase natural" para o esporte; na verdade, trata-se de uma construção identitária antiga, ligada à autorrepresentação do elevado grau de civilidade do crioulo, que só não obteria melhores resultados em função das dificuldades econômicas; b) a sugestão de que o colonialismo é o culpado por todos os problemas do arquipélago, uma noção que, em maior ou menor grau, tornou-se aparente no pós-independência.

$\mathrm{Na}$ verdade, desde o período colonial, equipes de Cabo Verde participavam de competições realizadas em outros países africanos (especialmente na Guiné-Bissau e em Angola) e em Portugal. ${ }^{18}$ Dessa vez, porém, seria diferente: a seleção nacional desfilaria os símbolos do país independente. Seria preciso, mesmo reconhecendo os limites, provar o valor da nação.

Assim, foi cercada de grande expectativa a participação do selecionado de Cabo Verde no evento na Guiné-Bissau. De um lado, havia a ânsia de estrear numa competição internacional; de outro lado, percebiase a preocupação com os resultados possíveis, algo que se acentuou em função de um mau desempenho da equipe em um amistoso preparatório:

17 Voz di Povo, ano 3 , n. especial, 22/04/1978, p.6.

18 Melo, Jogos de identidade; e Victor Andrade de Melo, "(Des)mobilização para a luta: o esporte como estratégia nos conflitos da Guiné Portuguesa (décadas de 50 e 60 do século XX)", Métis: História e Cultura, v. 10, n.19 (2011), pp.215-36. 
A descolorida e apática exibição que desagradou ao público que acorreu, em número razoável, ao Estádio da Várzea, não é compatível com o nível, ainda que modesto, do nosso futebol. Quanto mais não seja, espera-se mais brio por parte dos atletas a quem foi dada a honra de representar o futebol cabo-verdiano, sem perder de vista o aspecto essencialmente desportivo de nossa participação, que não pode ser ensombrada por "chauvinismo" ou nacionalismo exacerbado. ${ }^{19}$

Desde esses primeiros momentos de formação de uma seleção de futebol, valores ligados à nação estavam sendo mobilizados, mesmo que se fizesse uma ressalva a algum possível exagero (a um "nacionalismo exacerbado"). Da mesma forma, é perceptível a dificuldade de construir esse sentimento de nacionalidade, a exigência de certa postura frente ao novo ente (o país) que estava sendo erigido. No caso de Cabo Verde, terse-ia de lidar com várias fraturas internas, conflitos ligados a diferentes projetos políticos, que continuavam existindo, mesmo se tratando de um regime de partido único, e às rivalidades internas históricas entre as ilhas do arquipélago, dimensões que sempre manifestar-se-ão nos assuntos relativos ao esporte.

É nesse quadro que uma nova atividade esportiva internacional foi prevista para a comemoração do $3^{\circ}$ ano de independência (1978): um torneio para o qual foram convidadas representações de Angola, São Tomé e Príncipe, Guiné-Bissau, Moçambique, além da equipe nacional. É relevante registrar essa relação com outros países africanos de língua oficial portuguesa, celebrada nos campos de futebol.

Enquanto isso, continuavam os preparativos para a participação da seleção cabo-verdiana na Taça Amílcar Cabral. Houve uma primeira tentativa de formação de uma comissão técnica mais estável e de formulação de um calendário de preparação, que teve de lidar com a realidade de um país em que o futebol não era profissional, com a carência de recursos, com a distância entre as ilhas. Nesse quadro, ainda havia duas seleções separadas, uma das ilhas de Barlavento e outra das ilhas de Sotavento, ${ }^{20}$

19 Voz di Povo, ano 3, n.147, 05/06/1978, p.14.

20 O arquipélago é dividido em duas grandes regiões, por proximidade geográfica: Sotavento (formada pelas ilhas de Maio, Santiago, Fogo e Brava) e Barlavento (formada pelas ilhas de Santo Antão, São Vicente, Santa Luzia, São Nicolau, Sal e Boa Vista). 
que participaram de amistosos contra um time da província chinesa de Chantung, um evento que deve ser compreendido no marco das aproximações que Cabo Verde entabulou com os países do bloco socialista, na tentativa de estruturar a nação. ${ }^{21}$

Logo surgiu uma nova necessidade. Já que a perspectiva era de que a Taça Amílcar Cabral fosse um torneio oficial, as equipes deveriam se filiar à Federação Internacional de Futebol (FIFA) e à Confederação Africana de Futebol (CAF). Comum em países recém-independentes do continente, a iniciativa estava cercada de ambiguidades. Paul Darby, por exemplo, critica o grau de representatividade concedido a tais nações nas entidades esportivas internacionais. Para ele:

Análises empíricas podem demonstrar que o núcleo de membros europeus da FIFA tem tentado monopolizar o poder e recursos no mundo do jogo, procurando minimizar a presença ativa do Terceiro Mundo, restringindo a sua influência no centro das estruturas de tomada de decisão política do futebol mundial. ${ }^{22}$

De outro lado, o mesmo autor demonstra que a FIFA era uma das organizações internacionais em que os países da África tinham maior possibilidade de atuação. Isso se dava por alguns motivos: a) na entidade não havia diferenças de status nas votações, tendo cada associado igualmente um voto; b) os interesses comerciais apontavam o mercado africano como de potencial interesse; c) esse espaço se constituiu em função de uma aliança: o brasileiro João Havelange, em 1974, foi eleito para a presidência, a primeira vez em que um não europeu chegava ao cargo, para tal contando com o apoio dos, na época, chamados países do Terceiro Mundo, especialmente dos africanos, que se tornaram parceiros fiéis do dirigente, que, por sua vez, promoveu investimentos significativos para o desenvolvimento

${ }^{21}$ O país não era oficialmente alinhado ao bloco, mas mantinha com ele boas relações em função, inclusive, da proximidade dos regimes governamentais. No cenário do pós-Segunda Guerra Mundial, muitos países africanos recém-independentes mantiveram diferentes graus de relacionamento com o bloco, notadamente com a URSS. Em Cabo Verde, na transição de 1984 e 1985, pensou-se, inclusive, em contratar um técnico soviético para o selecionado. Para mais informações sobre tais relacionamentos no âmbito esportivo, ver: Baruch A. Hazan, "Sport as an Instrument of Political Expansion: the Soviet Union in Africa", in William J. Baker e James A. Mangan (eds.), Sport in Africa: Essays in Social History (Nova York: African Publishing Company, 1987), pp.250-71.

22 Paul Darby, Africa, Football and FIFA: Politics, Colonialism and Resistance, Londres: Frank Cass \& Co, 2002, p.241. 
do futebol nessas nações, usando para tal o patrocínio da Coca-Cola e da Adidas, e jogando, estrategicamente, com as polarizações entre capitalistas e socialistas, o que atenuava a força das ações dos associados europeus.

Vale citar que um dos sucessos da relação entre Havelange e os associados da África se deveu à sua contundente posição contra o apartheid. A FIFA, antes do Comitê Olímpico Internacional (COI), se colocou como aliada nessa luta. De fato, o cenário esportivo foi um dos principais fóruns de combate ao regime sul-africano. Assim, devemos ter em conta as palavras de John Sugden e Alan Tomlinson: "O futebol pode ser encarado tanto como um símbolo de imperialismo econômico e cultural quanto como um fórum de resistência do Terceiro Mundo à dominação e hegemonia do Primeiro Mundo". ${ }^{23}$

Conseguir a filiação a tais instituições não era, entretanto, tão simples. ${ }^{24} \mathrm{O}$ tema chegou a gerar certa tensão em Cabo Verde e nos outros países da chamada Zona 2. Ao fim, a competição foi organizada por uma associação "não oficial" do mundo do futebol, o Conselho Superior de Desportos da África, recebendo, todavia, o reconhecimento da entidade maior.

Internamente, as lideranças continuavam divididas. De um lado, percebia-se a celebração da possibilidade de participação internacional, uma posição que era sempre acompanhada da reivindicação de reestruturação do esporte nacional. Finalmente, Cabo Verde iria aparecer para o mundo, devendo, portanto, se esmerar para fazê-lo com qualidade técnica. De outro lado, alguns sugeriam que era necessário "Arrumar a casa primeiro e só depois participar lá fora":

Definir de antemão que tipo de desporto (competição ou de massas) se pretende erigir e posteriormente lançar as bases para o seu relançamento, deverá ser uma das primeiras tarefas da Direção Nacional de Educação Física e Desportos. Essa opção implica, desde já, uma tomada de posição clara a fim de se evitar a indefinição atual da nossa prática desportiva que ainda persiste nos moldes de antigamente. ${ }^{25}$

23 John Sugden e Alan Tomlinson, "Football and FIFA in the Postcolonial Word", in John Bale e Mike Cronin (eds.), Sport and Postcolonialism (Nova York: Berg, 2003), p.195.

24 Cabo Verde somente foi aceito na FIFA em 1986. O Comitê Olímpico de Cabo Verde foi fundado em 1989 e aceito oficialmente no COI em 1993.

25 Voz di Povo, ano 3, n.171, 06/12/1978, p.9. 
Nesse quadro de início de transição, a seleção cabo-verdiana embarcou para Bissau, a fim de tomar parte na $1^{\mathrm{a}}$ edição da Taça Amílcar Cabral. Chegara o grande dia. As cores da bandeira cabo-verdiana e os símbolos do país independente finalmente seriam exibidos em uma competição internacional "oficial", carregados por novos heróis que deveriam honrar a gloriosa história da jovem nação. Pouco importava que se tratasse de uma competição menor no quadro futebolístico mundial. Era o máximo que podia Cabo Verde naquele momento. Além disso, o torneio homenageava o grande líder Amílcar Cabral, cujas palavras e imagens foram eleitas pelo regime vigente como a maior representação do que deveriam ser seus concidadãos. ${ }^{26}$

A participação na Taça Amílcar Cabral foi também encarada como uma forma de fortalecer o projeto de Estado Único com a Guiné-Bissau. Por vezes, equipes cabo-verdianas para lá se deslocaram, para participar de comemorações ou festivais, ocasiões sempre encaradas como uma forma de reforçar os supostos laços de amizade entre os países. Antes houvera, inclusive, o já citado quadrangular de Bissau. Mas, dessa vez, o intuito era outro: celebrar, em uma competição oficial, o encontro de duas nações que pretendiam, em função de compartilharem as lutas contra Portugal no período colonial, compor uma administração integrada.

Logo, o envolvimento da equipe nacional de futebol com a competição atendia a pelo menos três importantes dimensões da política de Cabo Verde. Tratava-se de uma oportunidade para: exaltar a nova nacionalidade em construção; divulgar o nome do país no cenário internacional (e, quem sabe, até mesmo apresentar as benesses do novo regime, caso a seleção tivesse um bom desempenho); alinhar a nação com as causas pan-africanas.

26 A imagem de Amílcar Cabral era uma presença constante no arquipélago. Todas as edições do Voz di Povo, por exemplo, publicavam fotos e excertos de seus textos. Cabral nasceu na Guiné, mas era filho de cabo-verdianos. Voltou ao arquipélago com sete anos, onde estudou até se transferir para Portugal. Na metrópole, frequentou a Casa dos Estudantes do Império e o Instituto Superior de Agronomia, onde concluiu o ensino superior, ocasião em que tomou contato com o pensamento pan-africano. Mesmo tornando-se funcionário do governo português, foi um dos principais artífices das lutas coloniais entabuladas nas selvas da Guiné, ligadas à libertação dessa colônia e de Cabo Verde. É reconhecido como um dos mais importantes líderes africanos do pós-Segunda Grande Guerra. Para mais informações, ver: António Tomás, O fazedor de utopias - uma biografia de Amílcar Cabral, Praia: Spleen, 2008. 
O Voz di Povo enfaticamente celebra a chegada do selecionado a Bissau: "Cabo Verde na alta roda do futebol africano". ${ }^{27} \mathrm{O}$ tom da matéria, é verdade, não é lá muito otimista. Além dos problemas financeiros que cercaram a preparação, o jornal lembra que muitas empresas locais relutaram em dispensar seus funcionários para atuar na equipe nacional:

É compreensível que uma dispensa prolongada dos atletas possa não convir a um departamento estatal ou privado, mas como entramos na senda internacional, onde o desporto é um veículo de grande impacto, põe-se o problema de querermos ou não ter uma selecção que nos represente condignamente. ${ }^{28}$

Mesmo com vários limites, a nação ia entrar em campo. Segundo o olhar de alguns, seria o primeiro grande desafio internacional depois das lutas da independência nas selvas da Guiné. As emissoras de rádio cobriram fartamente o evento, atendendo a avidez da população caboverdiana por informações sobre a contenda.

Entretanto, confirmou-se o tom pessimista: os resultados não foram bons para a equipe do arquipélago. Antes de começar o jogo contra a Guiné-Bissau (ao fim, vencido pela equipe da casa por 3 x 0), o treinador de Cabo Verde informou que muitos jogadores foram atingidos por paludismo. É muito provável que seja verdade, pois esse era um problema comum naquele país, mas também se conseguira uma desculpa para o fato de que o selecionado não tenha feito nenhum ponto, nem marcado um gol sequer. A imprensa não deixou por menos: "panorama medíocre que caracterizou a sua actuação", "futebol descolorido, incaracterístico, cotando-se como a mais fraca do torneio"; "mais de 40 foras-de-jogo marcados contra Cabo Verde". ${ }^{29}$ A participação, enfim, foi considerada um desastre.

\section{Que desporto? À busca de um bom resultado}

Os maus resultados da seleção cabo-verdiana nas suas primeiras atuações internacionais contribuíram para acirrar as polêmicas. Mesmo que os

Voz di Povo, ano 4, n.174, 08/01/1979, p.11.

28 Voz di Povo, ano 4, n.174, 08/01/1979, p.11.

29 Voz di Povo, Ano 4, n.175, 17/01/1979, p.12. 
dirigentes, por ocasião da celebração do Dia dos Heróis, em janeiro de 1979, tenham reiterado a sua compreensão sobre a importância da prática, o campo esportivo entrou em ebulição, acentuada pelo fato de que, por problemas diversos, uma vez mais o campeonato nacional de futebol não tenha se realizado, como ocorrera no ano anterior. Para as lideranças do esporte, frente à dúvida entre massificar ou projetar internacionalmente o país, o governo não dava conta de nada.

Assim, uma velha pergunta retorna às páginas do jornal: "Que desporto em Cabo Verde?". ${ }^{30}$ As constatações são as de sempre, de maneira alguma infundadas: havia múltiplas dificuldades para que se implementasse uma prática esportiva de melhor qualidade, algo que se acentuava porque existiam outros setores estratégicos que o governo tinha que dar conta. Na verdade, todo o Estado estava em organização, tendo-se que equacionar os princípios ideológicos do PAIGC, o passado do arquipélago, as necessidades urgentes e as condições concretas de um país de escassos recursos.

É fato que várias modalidades continuaram a ser praticadas, alguns torneios organizados, os escolares mobilizados para competições. Todavia, continua a questão incômoda: se a participação esportiva internacional é considerada um elemento importante para a visibilidade do país, como formar equipes competitivas, contando com poucos recursos e ainda tendo de lidar com a ideia de que a principal função do governo era estimular a massificação e o forjar do novo homem cabo-verdiano?

Essa tensão está constantemente expressa nas páginas do $\mathrm{Voz} d i$ Povo: muitas críticas e sugestões, algumas iniciativas, aparentemente pouco avanço. No fim do ano de 1979, uma longa entrevista com o presidente da Comissão Administrativa da Federação Cabo-Verdiana de Futebol (a entidade ainda não fora oficializada), Joaquim Ribeiro, uma liderança esportiva dos tempos coloniais que voltava à ativa, sumarizava os desafios a serem enfrentados: falta de dinheiro, de campos em condições, de material adequado, de mão de obra qualificada; se o estádio de uma cidade entrava em obra, não havia outro lugar para jogar. ${ }^{31}$

30 Voz di Povo, ano 4, n.179, 14/02/1979, p.9. Essa questão foi muito debatida nos primeiros anos da independência. Para mais informações, ver: Melo, Jogos de identidade.

31 Voz di Povo, ano 5, n.215, 04/12/1979, p.9. 
Em grande parte da entrevista, o dirigente trata da dificuldade de consolidar um campeonato nacional de futebol, o que trazia problemas para a participação da seleção na Taça Amílcar Cabral. Como escolher os melhores sem jogos regulares? Sem tais partidas, como treinariam os atletas? Ribeiro ainda celebra, com esperança, o adiamento da competição para fevereiro: "poderemos achar uma solução que nos permita trabalhar a tempo e horas, e não à última da hora, para que a nossa presença se revista de dignidade num torneio a que não podemos deixar de dar a nossa presença. É um torneio demasiadamente expressivo em relação à época que Cabo Verde vive". 32

A promessa foi em vão. Alegando dificuldades financeiras, o país não enviou representação para a Taça Amílcar Cabral de 1980, realizada em Gâmbia. Isso alimentou ainda mais as polêmicas. Pelas páginas do Voz di Povo, vemos, por exemplo, o debate que houve entre Luís Carlos Vasconcelos, radialista, e Joaquim Ribeiro. Segundo o representante da Federação em formação, tratou-se de uma decisão superior, ainda que tenha sido autorizada a presença de uma delegação de dirigentes. Fez questão de refutar a acusação de que esses nada fizeram na viagem, argumentando que muito trabalharam no acompanhamento da competição. ${ }^{33}$

De outro lado, uma vez mais, nos festejos de comemoração da independência, entre as competições de várias modalidades, organizouse um quadrangular de futebol com seleções de Senegal, Guiné-Bissau e Guiné Conacri. Já se percebe uma melhor estruturação da equipe cabo-verdiana, treinada por Du Fialho, ${ }^{34}$ formada por 13 jogadores de São Vicente, oito de Santiago, quatro de Sal e um do Fogo. O esporte foi mesmo uma das bases das celebrações, sendo a mobilização da ideia de nacionalidade explícita ao seu redor.

$\mathrm{Na}$ verdade, ao final do ano de 1980, duas ocorrências tiveram significativo impacto no país: a promulgação da primeira constituição, que previa, inclusive, no seu artigo 16, parágrafo $3^{\circ}$, que "Incumbe ao Estado encorajar e promover a prática e difusão dos desportos e da cultura

Voz di Povo, ano 5, n.215, 04/12/1979, p.9.

33 Voz di Povo, ano 5, n.225, 12/03/1980, p.9.

34 Du Fialho foi um renomado jogador no arquipélago, tendo feito carreira em Portugal, no Benfica e no Lusitano de Évora. 
física"; e o golpe de Estado na Guiné-Bissau, o que daria fim ao projeto de construção de um Estado Único.

Acentuou-se um processo que já estava sensivelmente em marcha, mesmo que nem sempre de forma explícita nos discursos - a ideia de que o país deveria assumir uma identidade africana se relativizou: "com o fim da unidade, criaram-se as bases para uma paulatina desideologização da cultura, possibilitando o resgate parcial dos achados culturais claridosos, ${ }^{35}$ antes votados ao ostracismo, sem perda relativa para a herança afro-negra reabilitada". ${ }^{36}$

Antigos parâmetros ligados à representação de cabo-verdianidade voltarão a ser mobilizados, ainda que não exatamente como antes. Segundo Fernandes, ${ }^{37}$ finalmente são criadas as condições para forjar uma pátria cabo-verdiana ajustada com sua própria tradição histórica. Enfim:

Até a década de 1980 a elite do PAIGC buscou enfatizar a importância dos "combatentes", que, da mata da Guiné, teriam trazido a liberdade, minimizando o papel concorrente da luta dos seus quadros da clandestinidade que continuaram no arquipélago. Entre oitenta e noventa se destacou a importância dos movimentos culturais anteriores do PAIGC no processo de formação da nação cabo-verdiana. ${ }^{38}$

É nesse ambiente de reconciliação com o seu passado, e certamente de tensão interna, que a seleção de futebol se preparou para disputar a $3^{\mathrm{a}}$ edição da Taça Amílcar Cabral, a ser realizada em 1981, no Mali. Como de costume, houve problema no período de preparação, até mesmo corte de jogadores por problemas disciplinares. Todavia, reconhecia-se que eram notáveis os avanços, inclusive no que tange à estrutura de treinamentos: "Diariamente, a equipa fará dois treinos, sendo um baseado na educação física, e a outra na técnica individual. Há dois treinos conjuntos e serão dadas aulas de sistema táctico, regulamentos e leis de futebol". ${ }^{39}$

35 A Claridade foi não somente uma das mais importantes revistas da história do arquipélago, como também um dos casos mais notáveis de busca de uma identidade literária em uma colônia portuguesa. Ao seu redor, reuniram-se expressivos intelectuais/literatos que assumiram a causa da defesa do povo cabo-verdiano e da afirmação das peculiaridades culturais locais. Boa parte dos discursos identitários cabo-verdianos majoritariamente aceitos deve-se a suas ações.

36 Fernandes, Em busca da nação, p.235.

37 Fernandes, Em busca da nação, p.235.

38 José Carlos Gomes dos Anjos, Intelectuais, literatura e poder em Cabo Verde: lutas de definição da identidade nacional, Porto Alegre: UFRGS Editora, 2006, p.197.

39 Voz di Povo, ano 5, n.249, 31/12/1980, p.5. 
Segundo o técnico Du Fialho, que "lançou um apelo a todos os convocados, no sentido de encararem o trabalho, com seriedade e responsabilidade, banindo todo o espírito de infantilismo, para que saibam defender as cores nacionais, do país no Mali”, era uma ocasião perfeita para que o selecionado procurasse "praticar um futebol vistoso e disciplinado, dentro do espírito e concepção do desporto novo que Cabo Verde pretende erigir". ${ }^{40}$ Não faltaram polêmicas, mas, em geral, havia uma boa expectativa ao redor da participação da equipe do arquipélago na competição.

Um das situações mais tensas dessa edição do torneio foi o confronto entre Cabo Verde e Guiné-Bissau: ex-parceiros, rompidos diplomaticamente, emulavam seus conflitos numa partida de futebol. As notícias que chegavam do Mali davam conta da ambiência que cercava a ocasião:

Os jornalistas presentes na festa de Bamaco, ${ }^{41}$ atribuíram um caráter político ao jogo [...] quiçá porque a presença de Saúde Maria ${ }^{42}$ traduziu algo de importância, que não conseguimos descortinar. O clima era tenso entre os meios desportivos da capital $[\ldots]]^{43}$

Lembre-se que, de Cabo Verde, estava presente o Ministro da Educação e da Cultura, Carlos Reis. ${ }^{44}$ Aparentemente, entre os jogadores havia bom clima, mas é inegável que a tensão extravasava o campo.

Essa parece ter sido a grande vitória de Cabo Verde na competição: 3 x 0. Para o Voz di Povo foi a ocasião em que o selecionado "mostrou realmente o seu potencial, deu conta de si", já que se tratava de um jogo "decisivo visto que uma derrota significaria a decepção [...]". ${ }^{45}$ Para o jornal, a partida teria sido responsável por estabelecer uma relação de simpatia da torcida local para com a equipe do arquipélago.

No olhar do Voz di Povo, o desempenho do selecionado cabo-verdiano foi surpreendente, mesmo com os vários problemas que cercaram

40 Voz di Povo, ano 5, n.249, 31/12/1980, p.5.

${ }^{41}$ Capital de Mali.

42 Victor Saúde Maria foi Ministro do Exterior da Guiné-Bissau até 1982, tendo sido também Primeiro-Ministro até 1984.

43 Voz di Povo, ano 5, n.254, 23/02/1981, p.9.

44 Nas lutas coloniais, Reis trabalhou na Escola-Piloto e na Marinha. Participou ativamente das representações do PAIGC em Cabo Verde, no período de transição para a independência.

45 Voz di Povo, ano 5, n.254, 23/02/1981, p.9. 
a organização do evento (notadamente com a qualidade da alimentação oferecida, muito criticada). ${ }^{46}$ Comemora-se o que foi considerado um honroso $4^{\circ}$ lugar:

quando partimos da capital, séria responsabilidade pairava no espírito dos 20 jovens que condignamente representaram as cores nacionais: "Cabo Verde espera que cada jogador dê o máximo de si” — havia afirmado o Ministro da Educação e Cultura Carlos Reis. ${ }^{47}$

$\mathrm{Na}$ volta, o reconhecimento: os dirigentes do país consideraram esse resultado como um dos destaques anuais, digno de menção nos relatórios e balanços governamentais do ano. ${ }^{48}$

Para o Voz di Povo, a performance no Mali chamou a atenção para uma nação que ainda era pouco conhecida. Mais ainda: "Um futebol vistoso e disciplinado dentro do espírito e concepção do desporto novo que Cabo Verde projeta erigir foi praticado". ${ }^{49}$ Durante muitos anos essa foi comemorada como a primeira grande "vitória" internacional do país; os jogadores, não poucas vezes, foram chamados de "heróis de Bamako".

Essa participação contribuiu para fortalecer um processo que estava em curso. Paulatinamente, diminuíam as críticas ao envolvimento do país com o esporte internacional de competição, algo que se fortalecia com as expectativas geradas pelo fato de que Cabo Verde sediaria, em 1982, a Taça Amílcar Cabral.

O ano de 1981 foi de muitas novidades para o país. Na estrutura governamental, houve uma série de mudanças. O PAIGC deixou de existir no arquipélago, substituído pelo PAICV (Partido Africano da Independência de Cabo Verde). Na pasta de Educação e Cultura, responsável pelas questões do esporte, assumiu José Araújo. ${ }^{50}$ Constituiu-se uma nova comissão para se debruçar sobre a questão esportiva; sua composição permitia vislumbrar o quadro de transição, o equilíbrio entre o "antigo"

46 Houve, na trajetória da Taça Amílcar Cabral, muitos problemas de infraestrutura, algo compreensível pelo fato de os organizadores serem países com poucos recursos e pouca experiência na promoção desse tipo de evento. A alimentação era somente um dos pontos mais criticados.

47 Voz di Povo, ano 5, n.256, 17/03/1981, p.9.

48 Voz di Povo, ano 6, n.286, 01/01/1982, p.10.

49 Voz di Povo, ano 5, n.256, 17/03/1981, p.9.

50 José Araújo integrara, por parte do PAIGC, várias delegações de negociação da independência. 
e o "novo": Luís Fonseca (pela Juventude Africana Amílcar Cabral), João Burgo (pelo Ministério), Abailardo Barbosa (pelas Forças Armadas Revolucionárias do Povo), Antero Barros (pelo Ministério) e Joaquim Ribeiro (representante do desporto). Os três primeiros eram jovens dirigentes, os dois últimos antigas lideranças esportivas que atuavam desde os tempos coloniais.

Em longa entrevista concedida ao Voz di Povo, ${ }^{51}$ o Ministro dá algumas pistas da sua linha de atuação. Algumas ideias do antigo PAIGC ainda continuam presentes no discurso: "a política do governo em relação ao desporto assenta no valor que o partido reconhece, o desporto como fator de formação do homem novo em Cabo Verde". Todavia, marcará o novo momento uma ação bem mais pragmática.

Por exemplo, uma das discussões que persistia era sobre a necessidade de "africanizar o desporto", mas isso em boa medida passou a ser compreendido como inserir Cabo Verde nas instituições esportivas do continente. O Ministro continuou afirmando que isso daria "um novo alento à concepção da Unidade Africana", mas deixou escapar que um dos intuitos centrais era projetar o país internacionalmente.

José Araújo comemorava, assim, que a Ilha de São Vicente fora escolhida para sediar, em 1981, a $7^{\text {a }}$ Conferência dos Ministros de Juventude e dos Desportos da Zona 2, aberta pelo Primeiro-Ministro Pedro Pires, que, ao expressar o orgulho de Cabo Verde sediar o evento, conclamava que as decisões ajudassem a conceber uma prática esportiva que contribuísse para que a juventude africana se livrasse definitivamente de "heranças coloniais" e apontasse um futuro glorioso para o continente. ${ }^{52}$

Para o Ministro José Araújo, esse envolvimento do alto escalão era uma prova de que, passados alguns anos da independência, o esporte começara a ganhar espaço entre as preocupações governamentais, revertendo o que fora, do seu ponto de vista, "uma atividade marginal no período colonial, período em que, de um modo geral, as iniciativas não eram encorajadas e as atividades desportivas careciam de apoio". ${ }^{53}$ No seu modo de entender, naquela época, só havia interesse pelas "manifes-

51 Voz di Povo, ano 6, n.275, 14/10/1981, suplemento especial, p.1.

52 O discurso completo de Pedro Pires foi publicado em Voz di Povo, ano 6, n.277, 28/10/1981.

53 Voz di Povo, ano 6, n.275, 14/10/1981, suplemento especial, p.2. 
tações desportivas que poderiam servir aos objetivos de desmobilização no que tocava aos grandes problemas com que nosso povo se debatia".

Como pode ser visto, o discurso governamental ainda desconsiderava que a prática esportiva fora, em muitos momentos, uma alternativa de afirmação de uma ideia de caboverdianidade que, mesmo a princípio abandonada pelo PAIGC, estava a voltar com os novos arranjos políticos dos tempos do PAICV.

Um dos indicadores desse novo momento é exatamente o fato de o país ter assumido a responsabilidade de sediar a $4^{\mathrm{a}}$ edição da Taça Amílcar Cabral. Para o Ministro: "para nós isso tem uma importância de caráter político, podemos dizer, visto que essa taça traz o nome do fundador de nossa nacionalidade, para nós é importante que a sua disputa tenha também lugar na nossa terra". ${ }^{54}$ Mais ainda, ele lembrou que a organização do evento chamaria a atenção sobre o tema no cenário interno. Além disso, contribuiria para forjar uma boa imagem do país no continente africano.

Assim, na sessão de encerramento da $7^{\mathrm{a}}$ conferência, Araújo a todos convocou:

A vossa presença [...] seria interpretada por nós como uma homenagem dos desportistas continentais ao grande africano que foi o fundador da nossa nação, seria um estímulo a todos os desportistas cabo-verdianos, no momento em que começa uma nova etapa na marcha para um estágio superior do desporto cabo-verdiano. ${ }^{55}$

Na Guiné-Bissau, em 1979, a nação estreara nos campos internacionais. Um novo desafio fora assumido: o país deveria mostrar seu valor em outra estreia.

\section{Taça Amílcar Cabral: uma nova estreia da nação}

[...] é lógico que os poucos anos de existência não são de molde a extirpar totalmente da cabeça da nossa gente as sequelas de um passado marcante. Mesmo hoje, à luz de um desporto novo que se pretende edificar na nossa terra, permitindo não só o desenvolvimento psíquico e fisiológico do

\footnotetext{
54 Voz di Povo, ano 6, n.275, 14/10/1981, suplemento especial, p.2.
}

55 Voz di Povo, ano 6, n.278, 05/11/1981, p.8. 
atleta que o pratica, como contribuindo para o reforço da unidade nacional e ainda a criação do espírito de solidariedade mutua entre os cidadãos. ${ }^{56}$

No decorrer de 1981, os dirigentes esportivos de Cabo Verde, ao mesmo tempo em que mantinham os discursos à moda do PAIGC e reajustavam certas práticas ao jeito do PAICV, melhor estruturando uma política nacional de esportes, se dedicaram com denodo a organizar a $4^{\mathrm{a}}$ Taça Amílcar Cabral.

De fato, como nunca antes no país independente, o esporte ocupara as atenções governamentais. Se a participação na $1^{\mathrm{a}}$ edição da Taça Amílcar Cabral significara a grande estreia do país no cenário esportivo internacional, naquela ocasião, mais ainda, tratava-se de demonstrar que Cabo Verde tinha condições de receber delegações estrangeiras e promover um evento de qualidade. Colocava-se à prova sua capacidade organizativa, sua condição de ser aceita no grande tabuleiro geopolítico do continente: não era uma questão somente esportiva, a jovem nação estava em jogo.

Nas páginas do Voz di Povo dos meses finais do ano de 1981, percebe-se a grande mobilização que havia ao redor do evento. As apreensões estavam relacionadas com as condições concretas de o país organizá-lo adequadamente, dispondo de recursos limitados para tal:

A Taça Amílcar Cabral fez com que Cabo Verde assumisse, no plano continental, compromissos importantes com os quais pretende melhorar sua imagem desportiva no solo africano. Por isso, julgamos, a Taça Amílcar Cabral não pode falhar. Se na Conferência de Mindelo, a imagem de nosso país começou a melhorar no plano desportivo continental, a $4^{\mathrm{a}}$ edição da Taça Amílcar Cabral permitirá a Cabo Verde fazer mais e melhor. ${ }^{57}$

Duas eram as preocupações principais. A primeira era a conclusão das obras dos estádios que receberiam os jogos: a "valorização das estruturas desportivas tendo em vista a realização da próxima edição da Taça Amílcar Cabral no nosso país". ${ }^{58}$ A apreensão era grande:

Voz di Povo, ano 6, n.274, 07/10/1981, p.9.

57 Voz di Povo, ano 6, n.279, 12/11/1981, p.9.

58 Voz di Povo, ano 6, n.286, 01/01/1982, p.10. 
Aprazado para meados do próximo mês [...], o primeiro a editar-se em Cabo Verde, tem levantado, sobretudo nesta ponta final, perguntas de vária ordem - nomeadamente a que diz respeito à viabilidade de sua consecução, pelo menos na capital do país, visto que as bancadas (montáveis) para o estádio da Várzea (palco escolhido para a fase final do referido torneio) ainda não chegaram à Praia. Segundo se diz, um temporal surto ultimamente em Lisboa é a razão principal deste atraso. Todavia, é quase certo que ainda cheguem a tempo. Reforçando o turno (ou turnos) de trabalho no estádio da Várzea, as infraestruturas estarão prontas a tempo. Bem, até lá, aguardemos. ${ }^{59}$

No que tange à infraestrutura, havia ainda a necessidade de providenciar alojamentos para as equipes convidadas:

Outro problema "bicudo" é o que se refere ao alojamento dos componentes das representações dos sete países participantes (além do nosso). Dada a carência de hotéis, várias hipóteses de solução têm sido postas e estudadas, não se tendo, porém, à data, encontrado a mais conveniente. As instalações do Liceu Domingo Ramos são as que, após uma análise estruturada, oferecem as melhores condições. Todavia, optar pela interrupção do ano letivo em curso, por um período não inferior a duas semanas, não daria azo a maldosas especulações? Seria bem recebida pelos elementos, ligados ou não ao ensino, uma antecipação das férias da Páscoa? Enfim, perguntas que exigem uma resposta. $\mathrm{O}$ torneio, esse esperamos que se realize. Para o bem do desporto destas ilhas, tão carentes de contacto a nível do desporto internacional. ${ }^{60}$

A outra grande preocupação era a preparação da equipe nacional. Foi até mesmo suspenso o campeonato nacional para que mais cedo os jogadores pudessem ser convocados para os treinos, que acabaram sendo realizados na Ilha do Fogo, já que não havia melhor alternativa frente à impossibilidade de usar os espaços de Praia e Mindelo, que estavam em obras.

Aos poucos, os problemas foram resolvidos. $\mathrm{O}$ tom das cobranças tornou-se mais ameno, reconhecendo-se os avanços:

[...] parecia um empreendimento bem árduo, senão audacioso e até penoso, levando em conta as infraestruturas existentes em Cabo Verde,

59 Voz di Povo, ano 6, n.287, 08/01/1982, p.12.

60 Voz di Povo, ano 6, n.287, 08/01/1982, p.12. 
com especial relevo para as instalações inadequadas e mesmo obsoletas do estádio da Várzea. Ainda há bem pouco tempo, um rol de problemas [...] adensava-se, qual nuvem negra, de forma a desencorajar os melhores optimistas. [...] as coisas foram sendo resolvidas, cada uma a seu tempo [...] só resta aguardar pelo início do torneio, que, segundo tudo leva a crer, irá decorrer em bom plano, atendendo, como não podia deixar de ser, às limitações de um país pequeno e pobre. ${ }^{61}$

No que tange ao desempenho da seleção, o técnico Du Fialho, mesmo reconhecendo os limites de tempo e das condições de treinamento, exaltou os esforços dos jogadores e apontou perspectivas alvissareiras:

[...] Se a selecção [...] jogar com velocidade, se lutar e cumprir o que dela se espera, todos os cabo-verdianos vão sentir-se orgulhosos. [...] Os seleccionados praticamente não cometeram nenhum ato de indisciplina. São educados e estou optimista. [...] Todos os cabo-verdianos apoiem a turma cabo-verdiana, o que não significa que deixem de apoiar as boas jogadas dos nossos adversários. ${ }^{62}$

Para o Voz di Povo, o melhor possível foi feito para que tudo estivesse pronto no dia 10 de fevereiro de 1982, data da cerimônia de abertura do que então foi celebrado como o maior acontecimento da história esportiva de Cabo Verde. A capa do periódico celebrava: "Aristides Pereira e Pedro Pires ${ }^{63}$ abrirão a festa da Zona 2". ${ }^{64}$ Como afirmou o Ministro José Araújo, “isso porque queremos marcar a importância que atribuímos a esse acontecimento [...] que aumentará o prestígio de Cabo Verde na arena internacional". ${ }^{65}$

Essa dimensão seria celebrada, em muitos momentos, no decorrer do evento. Foi esta a manchete do Voz di Povo no dia do encerramento: "Em Cabo Verde o desporto na promoção da Unidade Africana" ${ }^{66}$ Para o Ministro José Araújo:

${ }_{61}$ Voz di Povo, ano 6, n.291, 10/02/1982, p.10.

62 Voz di Povo, ano 6, n.291, 10/02/1982, p.10.

${ }_{63}$ Pereira e Pires foram importantes líderes das lutas coloniais. Durante muitos anos, foram presidente e primeiro-ministro do país.

${ }^{64}$ Voz di Povo, ano 6, n.291, 10/02/1982, p.12.

${ }_{65}$ Voz di Povo, ano 6, n.291, 10/02/1982, p.9.

${ }^{66}$ Voz di Povo, ano 6, n.292, 20/02/1982, p.1. 
"me parece que uma Taça a ser disputada num contexto deste tipo [de "afirmação da personalidade africana e de definição de vontade da Unidade Africana"], não podia ter um melhor nome do que o de A. Cabral, homem que acreditou na união dos povos africanos" ${ }^{67}$

A imagem do líder, aliás, foi ainda mais veiculada e mobilizada, inclusive relembrando-se sua estreita ligação com a prática esportiva. ${ }^{68}$ Houve até mesmo ampla distribuição de um pôster comemorativo com sua fotografia. ${ }^{69}$

O Voz di Povo deu ampla cobertura à competição, inclusive com a publicação de muitas imagens: dos novos estádios, das delegações, das partidas, da torcida. Emissoras de rádio atuaram ainda mais, atualizando com maior frequência a população, que se envolveu e acompanhou de perto o que acontecia. As fotos dão conta de que as arquibancadas estavam sempre lotadas. As autoridades governamentais foram presença constante nos jogos e atividades. Enfim: "Durante cerca de duas semanas, Cabo Verde viveu, neste mês de fevereiro do ano da graça de 1982, o seu maior acontecimento desportivo de sempre, a IV edição da Taça Amílcar Cabral". ${ }^{70}$

“Com a lotação do Estádio da Várzea esgotada, no meio de um barulho ensurdecedor de tambores, gritos de incitação à nossa seleção e música tocada pelo conjunto 'Os Tubarões', perante a presença alegre de centenas de bandeiras multicores", a equipe nacional deixou de ir à final, em um jogo com tintas épicas, ao perder por 1 x 0 para o selecionado da Guiné Conacri, um gol marcado no fim da partida. Os atletas de Cabo Verde "saíram de campo com lágrimas nos olhos, tristes porque a adversidade fez com que perdessem uma partida que poderiam ter ganho, depois de terem lutado de forma tão brava". ${ }^{71}$ De qualquer maneira, o $4^{\circ}$ lugar foi considerado uma boa colocação. A seleção cabo-verdiana foi ainda eleita a mais disciplinada do torneio, e um de seus jogadores, Bala, o melhor da competição.

67 Voz di Povo, ano 6, n.292, 20/02/1982, p.8.

68 Para uma discussão sobre a importância do esporte na vida e nas ações de Amílcar Cabral, ver: Melo, "(Des)mobilização para a luta".

69 Voz di Povo, ano 6, n.291, 10/02/1982, p.10.

70 Voz di Povo, ano 6, n.293, 05/03/1982, p.11.

71 Voz di Povo, ano 6, n.293, 05/03/1982, p.11. 
Houve, é verdade, polêmicas no que tange à participação do país. As principais ressalvas parecem ter vindo de dirigentes, esportistas e jornalistas de São Vicente, que vinham criticando a atuação do técnico Du Fialho desde a fase de preparação. Mais ainda, criticava-se a cobertura dos meios de comunicação, tanto do $\mathrm{Voz}$ di Povo quanto da rádio oficial, supostamente muito elogiosa. Silvestre Rocha enfrenta o debate:

Vem isto a propósito das desonestas críticas de certo setor tendencioso do público de São Vicente, que achou exageradas nossas opiniões favoráveis à nossa seleção, aos nossos jogadores, a nosso selecionador Du Fialho e à forma esforçada e patriótica e altamente desportiva como os nossos rapazes jogaram [...]. Não houve exagero, nem no que dissemos nem no que escrevemos. ${ }^{72}$

É certo que o periódico oficial expressava majoritariamente pontos de vista que interessavam ao governo, podendo mesmo, portanto, resvalar para o exagero. Contudo, vale ter em conta que, em vários momentos, foram publicadas matérias críticas à ação governamental. Pelo que foi possível apreender, havia mesmo, ao redor da Taça Amílcar Cabral, uma grande euforia popular, algo que o jornal ajudou a alimentar e traduzir. Além disso, é possível inferir que em grande medida a representação foi de que o evento trouxe boas repercussões para o país, tanto no cenário interno quanto no externo.

A despeito da baixa qualidade técnica dos jogos, celebrava-se a continuidade da taça, considerada pelas lideranças como uma iniciativa fundamental para que se aperfeiçoasse a performance do futebol no continente:

O africano nasce com o gosto pela bola mas é prejudicado pelas condições desfavoráveis do meio, pelo facto de certos Governos não encararem o futebol como forma de educação e por uma excessiva politização do desporto. Se os futebolistas africanos dispusessem dos mesmos meios materiais e condições que têm os europeus e sul-americanos, competiriam em igualdade de circunstâncias com estes. No entanto, têm-se registrado nítidos progressos no futebol africano $[\ldots]^{73}$

Voz di Povo, ano 6, n.294, 15/03/1982, p.12.

73 Voz di Povo, ano 6, n.292, 20/02/1982, p.8. 
Além disso, muitos foram os elogios à boa organização. Celebravase "o exemplo cabo-verdiano", a capacidade de um país, mesmo pequeno, se mobilizar e demonstrar organização e dinamismo, glorificando o exemplo que Amílcar Cabral deixara. Ao publicar a fala do Ministro dos Desportos de Senegal, o Voz di Povo dá a entender que foram alcançados os desejados resultados de repercussão internacional:

Há coisas que não se dizem em público, mas como estamos entre desportistas podemos dizê-las. Todos nós tivemos desconfianças sobre a capacidade de Cabo Verde conseguir organizar esta quarta edição [...]. Temos de reconhecer com muita satisfação que se tratou da melhor organização de sempre [...]. [Todos] foram unânimes em concordar que tudo bateu certo, tudo correu à moda do planeado. ${ }^{74}$

Ao promover a Taça Amílcar Cabral, uma vez mais a nação demonstrara seu valor. Ou pelo menos essa parece ter sido uma apreensão muito forte no arquipélago naquele início de 1982.

\section{Mais taças: a nação em transição}

Com o apoio de nossa embaixada, ireis ser o nosso espelho, o espelho de Cabo Verde, daquele Cabo Verde que é conhecido com uma terra miserável, como uma terra pobre que manda os nacionais para fora a fim de sobreviverem. Vamos pois provar que Cabo Verde quer ir para a frente, que vamos avançando no caminho do progresso. É esse Cabo Verde novo que vão representar. ${ }^{75}$

No decorrer da década de 1980, frente à escassez de recursos, uma das estratégias adotadas pela administração cabo-verdiana foi a chamada "extroversão da economia": buscava-se tirar proveito da localização geográfica do arquipélago, que se situa no meio do caminho de três continentes (América, Europa e África). Pretendia-se: “incentivar, apoiar e orientar a ação do setor privado para o desenvolvimento econômico de Cabo Verde, considerando o investimento estrangeiro essencial para

74 Voz di Povo, ano 6, n.293, 05/03/1982, p.11.

75 Voz di Povo, ano 11, n.609, 19/01/1987, p.14. Frase proferida por David Hopffer Almada, Ministro da Informação, Cultura e Desportos, por ocasião da participação da seleção cabo-verdiana de futebol em um torneio. 
a viabilização do projeto de expansão da economia nacional". ${ }^{76} \mathrm{Com}$ a adoção do multipartidarismo, em 1991, já desde o primeiro governo, sob a direção de um novo partido, o Movimento Para a Democracia (MPD), essa tendência se acentuaria com o chamado "Modelo de Inserção Dinâmica de Cabo Verde".

Sinais desse novo quadro podem ser sentidos no cenário esportivo e no tocante ao envolvimento do país com a Taça Amílcar Cabral. Um deles foi o restabelecimento de uma maior relação com Portugal. Buscou-se aumentar o intercâmbio com a antiga metrópole, chegando-se a aventar o envio do selecionado para temporadas na Europa, nas quais seria orientado por treinadores daquele país. O antigo colonizador, afastado desde a independência, voltava a ser encarado como parceiro em potencial.

Uma das ações imediatas foi a permissão para que fossem convocados para o selecionado jogadores de origem cabo-verdiana que atuavam em equipes portuguesas:

[...] a Federação entendeu que a nossa equipa poderia ser reforçada com a presença de jogadores cabo-verdianos que, actualmente, militam em equipas portuguesas. Não se trata de uma situação inédita, porque todo o mundo sabe que muitas nações chamam os seus jogadores no estrangeiro, quando se tornam indispensáveis, ou úteis às selecções dos seus países. ${ }^{77}$

A decisão pode parecer usual, mas não o era se considerarmos os intuitos originais do partido único e o fato de que ainda era recente o rompimento dos laços coloniais. A justificativa demonstra que um novo quadro de pragmatismo se impunha:

O futebol, principalmente quando atinge o nível de internacionalizações, já não vive de sentimentalismo, nem de especulações de caráter demagógico. Precisa, isso sim, de aproveitamento integral da sua potencialidade, nomeadamente quando se pretende entrar na realidade, a expressão máxima de nossa atividade. ${ }^{78}$

De toda forma, havia uma ressalva. Mais do que para respeitar

${ }_{76}$ Daniele Ellery, Identidades em trânsito, Campinas: Arte Escrita, 2009, p.63.

77 Voz di Povo, ano 7, n.343, 10/06/1983, p.12.

78 Voz di Povo, ano 7, n.343, 10/06/1983, p.12. 
uma legislação internacional, tratava-se de uma clara expressão de que se pretendia resguardar, pelo menos simbolicamente, as conquistas que advieram com a independência:

[...] só serão chamados aqueles que mantêm a nacionalidade cabo-verdiana e que nunca foram internacionais portugueses. Assim, é estranho que se possa dizer que alguns dos que virão jogaram já por selecções de Portugal. Importa, pois, que fique esclarecido este aspecto para se evitarem futuras especulações. ${ }^{79}$

Essa decisão ocasionou muitas polêmicas. Do ponto de vista operacional, devia-se coordenar o calendário do selecionado cabo-verdiano com as obrigações dos atletas com seus clubes portugueses, sempre reticentes em ceder seus "funcionários". Houve também os que criticaram a novidade por julgá-la um alinhamento desnecessário com o antigo colonizador, um retrocesso no processo de independência. A isso se somaram as queixas dos que atuavam nas equipes de Cabo Verde, que perdiam seu espaço com a chegada de futebolistas melhor preparados. Como sugeriu o jogador Bassana: "A selecção é um prêmio justo para os jogadores que estão cá. Não temos nada aqui e, por isso, a selecção é para nós um estímulo". ${ }^{80}$

Para alguns, existia ainda outro problema a considerar: desconfiava-se de que os convocados que atuavam no futebol português tinham perdido "a raiz cabo-verdiana, devido, em grande parte, à formação adquirida no estrangeiro". ${ }^{81}$ De fato, deve-se registrar que houve mesmo choques culturais entre os cabo-verdianos de Cabo Verde e os cabo-verdianos de Portugal.

Na verdade, a decisão tocava em ponto fulcral: migração e diáspora, temas constantes na história do arquipélago. Dada a contundência do quadro, o governo possuía programas de mapeamento, apoio e reinserção de emigrantes. Dados de Katia Cardoso ${ }^{82}$ indicam que na ocasião havia cerca de 300.000 cabo-verdianos/familiares nos Estados Unidos, 83.000

79 Voz di Povo, ano 7, n.343, 10/06/1983, p.12.

80 Voz di Povo, ano 9, n.349, 28/01/1984, p.12.

81 Voz di Povo, ano 8, n.349, 13/08/1983, p.1.

82 Katia Aline Lopes Rodrigues Cardoso, "Diáspora - a (décima) primeira ilha de Cabo Verde: a relação entre a emigração e a política externa cabo-verdiana" (Dissertação de Mestrado, Instituto Superior da Ciência do Trabalho e da Empresa, 2004). 
em Portugal, 25.000 na França, 16.000 na Holanda, 3.000 em Luxemburgo, além de comunidades na Suécia, Noruega, Alemanha e Bélgica, entre outros países (inclusive o Brasil). Em 2010, informava-se no sítio oficial do governo que:

A população residente no país é estimada em 434.263 habitantes, sendo uma população jovem com média de idade de 23 anos. A falta de recursos naturais e as escassas chuvas no arquipélago determinaram a partida de muitos caboverdianos para o estrangeiro. Atualmente a população cabo-verdiana emigrada é maior do que a que vive em Cabo Verde. ${ }^{83}$

O futebol, aliás, convém que se note, tem uma "diáspora própria". John Bale informa que, em 2002, dos 311 atletas de 16 seleções da Copa da África, 193 jogavam na Europa (ou seja, 62\%); as equipes de Camarões, Nigéria e Senegal eram quase integralmente formadas por jogadores que atuavam fora do país de origem. Em 1999, havia cerca de 890 africanos em clubes europeus. ${ }^{84}$ Portugal era um dos países que mais recebia futebolistas. Angola era o que mais enviava atletas, 93\% deles para a antiga metrópole. ${ }^{85}$

Voltando ao caso cabo-verdiano dos anos 1980, em função das múltiplas tensões, mesmo com a permissão, por vezes sequer se convocavam os jogadores que atuavam em Portugal. Houve ainda um grande conflito quando fora convidado, na transição dos anos de 1985 e 1986, como técnico da seleção o sanvincentino Carlos Alhinho, que tivera uma longa carreira de jogador em Portugal. Seu tempo à frente da equipe nacional foi marcado por muitas polêmicas ligadas a seus comportamentos e à sua lista de selecionados, que privilegiava os que jogavam em São Vicente. Assim se referiu a ele, em determinada ocasião, o Voz di Povo: "Carlos Alhinho ignora a realidade nacional e não conseguiu penetrar no meio". 86

83 Disponível em: <http://www.governo.cv/>, acessado em 23/01/2013.

${ }^{84}$ John Bale, "Three Geographies of African Footballer Migration: Patterns, Problems and Postcoloniality", in Gary Armstrong e Richard Giulianotti (eds.), Football in Africa: Conflict, Conciliation and Community (Nova York: Palgrave Macmillan, 2004), pp.229-46.

85 Para mais informações sobre a migração de jogadores africanos, ver: Rafaelle Poli, "Migrations and Trade of African Football Players: Historic, Geographical and Cultural Aspects", Afrika Spectrum, v.41, n.3 (2006), pp.393-414.

${ }^{86}$ Voz di Povo, ano 11, n.517, 15/01/1986, p.9. 
De toda forma, em 1983, com a chegada dos que atuavam em Portugal, aumentaram as expectativas de obtenção de bons resultados na $5^{\text {a }}$ Taça Amílcar Cabral, a ser realizada na Mauritânia. No entanto, a esperança não se materializou. A princípio não se imputou aos novos jogadores a responsabilidade pelo mau desempenho: "É de toda a justiça realçar o espírito de sacrifício desses atletas que, embora sabendo que correm alguns riscos para a sua carreira de profissionais de futebol, não deixaram de responder à chamada para representar a seleção do seu país". ${ }^{87}$ Posteriormente, porém, ninguém foi isento de culpa.

"Ainda não foi desta vez a nossa chance":88 essa é a manchete da matéria que comenta o mau resultado - Cabo Verde sequer alcançou as semifinais. O treinador Du Fialho, demitido no decorrer da competição, foi apresentado como alguém que "não ouve a opinião de ninguém, não procura ensinar". Para o jornal, os jogadores encararam as partidas "de maneira pouco responsável, sem amor à camisola". Resumindo, segundo o olhar do periódico: "Os cabo-verdianos não reagem, como manda a ética futebolística. Sem força anímica, sem capacidade de ataque nem o espírito colectivista - mesmo sem vontade de jogar — a selecção continuou a actuar sob o lema "cada um por si e deus por todos"”. Isso era considerado ainda mais grave por tratar-se da participação em uma competição tão importante,

[...] uma festa de oito nações da África Ocidental: é uma homenagem a um grande homem, que também foi futebolista. É a expressão, a vontade de um punhado de países em busca de uma identidade desportiva. Se, nas anteriores edições, o nome de AMÍLCAR CABRAL foi sempre respeitado, a próxima [...] virá divulgar, ainda mais, a figura daquele que foi um dos melhores filhos da África. ${ }^{89}$

Ausência de estratégia para o desenvolvimento do esporte nacional: essa era a acusação mais constante e contundente. Entretanto, parece inegável que as coisas paulatinamente foram se organizando. Um exemplo pode ser visto nos preparativos para a participação do selecionado na edição de 1984 da Taça Amílcar Cabral, realizada em Serra Leoa. Dessa vez, conseguira-se não só uma preparação bem planejada, como

${ }_{87}$ Voz di Povo, Ano 7, n.347, 21/07/1983, p.1.
88 Voz di Povo, ano 8, n.348, 06/08/1983, p.6.
89 Voz di Povo, Ano 7, n.347, 21/07/1983, p.1. 
também estruturar melhor a presença da equipe na sede das competições. Lograra-se até mesmo conseguir horário de voos mais adequados (com a participação da Transportes Aéreos Cabo Verde) e a inclusão de um cozinheiro na delegação, para resolver o comum problema da inadequação da comida oferecida no local da competição.

A despeito dos avanços, os fracassos se sucediam. A avaliação das derrotas sempre resvalava na ideia de nação como um todo e explicitava os limites do país que se tentava erigir. Vejamos como se resume a participação do selecionado no certame de 1984:

C. Verde voltou a ficar pelo caminho

$[\ldots]$

Para uma campanha futebolística de pouca dura [...], não vale a pena alongarmo-nos em comentários e lamentações. Conhecidas as limitações de vária ordem e que envolvem o nosso futebol, em particular, e o nosso desporto, em geral, só por um feliz acaso a selecção cabo-verdiana regressaria da Serra Leoa coberta de glória. Depois do revés [...], valha-nos ao menos a consciência das nossas limitações no desporto e a decisão de criar as bases necessárias ao seu florescimento. O desporto, como aliás qualquer outro sector da vida social, necessita de estruturas sérias, trabalho aturado e muita dedicação. ${ }^{90}$

Tratou-se da pior participação de Cabo Verde: sétimo lugar. Como prêmio de consolação, Manuel Reis foi escolhido o melhor árbitro da competição, uma decisão curiosa, já que esse era um dos problemas mais criticados pelas lideranças esportivas do arquipélago. Com ironia assim registrou-se no jornal: “A arbitragem cabo-verdiana está muito mais evoluída do que o futebol praticado hoje no nosso país". ${ }^{91}$

Após cada competição, ocorria aproximadamente o mesmo: o apontamento de velhos problemas, a reedição de antigas acusações e desculpas, uma certa desorientação sobre que caminho tomar tendo em vista os limites e possibilidades do país. Por vezes, as justificativas pareceriam muito curiosas se não se levar em conta a realidade local: " $O$ jogador cabo-verdiano tem sempre dificuldade em actuar na relva, o que

90 Voz di Povo, ano 9, n.373, 18/02/1984, p.12.

91 Voz di Povo, ano 9, n.375, 03/03/1984, p.12. 
é bastante normal. Temos jogadores que não se adaptaram ao relvado durante todos os jogos". ${ }^{92}$

O fato é que, até 1984, em 17 jogos disputados na Taça Amílcar Cabral, Cabo Verde somente vencera quatro. Reverter essa situação tornara-se uma obsessão, uma vez que, na avaliação de alguns, havia "matéria-prima" para tal. A frase de Bobo Keita, um ex-esportista de sucesso e um dos líderes das guerras coloniais na Guerra da Guiné, resume a apreensão geral: "Para mim, o jogador cabo-verdiano é, na sua essência, muito mais cerebral e imaginativo do que os restantes em confronto, mas, não tem a preparação que sofrem os outros". ${ }^{93}$

Que solução? Estabelecer maior número de contatos internacionais passou a ser uma saída por todos apontada. De fato, aumentaram as iniciativas de intercâmbio. Atletas cabo-verdianos de atletismo participaram das Espartaquíadas (jogos dos povos da URSS). Posteriormente, alguns fariam estágio naquele país. Recebeu-se apoio de outras nações socialistas, como a Alemanha Oriental e Cuba. Senegal passou a ser considerado um dos principais parceiros. Como lembra Fernandes, ${ }^{94} \mathrm{em}$ todos os âmbitos essa foi uma das estratégias de reconstrução do Estado.

Mas, em geral, as iniciativas não tinham o sucesso imediato esperado. Por vezes, as coisas ainda pioravam. Por exemplo, em função dos conflitos ocasionados com a contratação (e demissão) de Carlos Alhinho, por decisão do, na época, Ministro da Educação Corsino Tolentino, a seleção de Cabo Verde não compareceu à $7^{\mathrm{a}}$ Edição da Taça Amílcar Cabral, realizada em fevereiro de 1986, no Senegal. A década terminaria sem um grande resultado.

O futebol, enfim, parecia dramatizar algumas questões da estruturação do Cabo Verde independente. Além das constantes tensões internas, tanto entre Santiago e São Vicente quanto entre os diferentes projetos de país, havia temas que pareciam afligir a todos. Como coadunar os desejos de sucesso com as limitações concretas? Como conseguir um espaço maior no cenário internacional? Sendo um país pequeno e de

\footnotetext{
92 Voz di Povo, ano 9, n.375, 03/03/1984, p.9. Em função das condições climáticas, das características do solo e da escassez de água e, logo, das consequentes dificuldades para cultivar grama, em Cabo Verde a maioria dos campos é de terra.

93 Voz di Povo, ano 10, n.421, 02/01/1985, p.8.

94 Fernandes, Em busca da nação.
} 
poucos recursos, como não ser subalterno nesse quadro? Como fazer isso, sem perder suas peculiaridades? Como se relacionar com o antigo colonizador sem retomar os parâmetros de país colonizado?

\section{À guisa de conclusão: a conquista da Taça Amílcar Cabral}

Em 2000, quase dez anos após a adoção do multipartidarismo, quando Cabo Verde sediava de novo a Taça Amílcar Cabral (a 12a edição), a seleção nacional, enfim, sagrou-se vencedora na final disputada contra a equipe de Senegal $(1 \times 0)$. O país inteiro comemoraria a sua maior conquista esportiva internacional. ${ }^{95}$

No blog "Café Margoso", de João Branco, há um interessante debate ligado a essa conquista. ${ }^{96} \mathrm{O}$ autor recorda que, na ocasião, "uma grande festa tomou conta da cidade de Mindelo". Ocorre que, no mesmo dia, também o Sporting sagrou-se campeão nacional de Portugal. Assim:

O povo saiu à rua. Quem visse concluiria que a seleção cabo-verdiana equipava de verde e tinha o leão como o símbolo maior, porque era essa a cor e a figura dominante na grande festa popular [...]. A festa foi muito mais verde que azul. A verdade é que houve mais rugidos de leão do que mordidas de tubarão (os selecionados crioulos têm a alcunha de tubarões azuis).

Essa é uma questão que continua polêmica no arquipélago: o relacionamento com o antigo colonizador. Odair Rodrigues, no artigo "Benfica ou Seleção Nacional?", publicado, em 3 de maio de 2010, ${ }^{97}$ comenta as intensas festas populares que houve nas ruas de várias ilhas do arquipélago, motivadas pela conquista de um campeonato pelo Benfica, que conta com muitos adeptos em Cabo Verde. Para o autor, é curioso que os jovens demonstrem tanto entusiasmo pela equipe lisboeta e tão pouco envolvimento com as agremiações locais:

95 O selecionado nacional ainda chegaria uma vez mais à final da Taça Amílcar Cabral, em 2007, perdendo, contudo, a partida decisiva para Mali, por 2 x 1. Já fora vice, em 1991, e obtivera o $3^{\circ}$ lugar, em 1989. Fez ainda boa campanha nas eliminatórias para a Copa do Mundo de 2010, mas continua sendo um sonho estar presente no maior evento esportivo mundial. No que tange à Copa Africana de Nações, sua única participação foi em 2013.

96 Disponível em: <http://cafemargoso.blogspot.com/2010/05/declaracao-cafeana_11.html>, acessado em 23/01/2013.

97 Disponível em: <http://daivarela.blogspot.com.br/2010/08/benfica-ou-seleccao-nacional.html>, acessado em 23/01/2013. 
É uma triste aculturação dos jovens cabo-verdianos. Temos um fanatismo doentio por equipes de um país que nos dominou durante séculos e que depois votou-nos ao esquecimento nos seus manuais de História. Grande parte dos jovens estudantes portugueses desconhece a localização de Cabo Verde num mapa-múndi. Depois de termos sido colonizados por Portugal, hoje muitos portugueses sabem da nossa existência porque há cabo-verdianos nas terras lusas. Enquanto isso, somos mais benfiquistas do que um lisboeta.

Para Rodrigues, o problema maior não é torcer por equipes estrangeiras, mas desprezar as cabo-verdianas. Isso teria relação com a atuação dos meios de comunicação locais, que valorizavam demasiadamente o esporte português, chegando a chamar de "seleção nacional" a equipe representativa da ex-metrópole.

João Branco não concorda com parte das observações de Rodrigues. Para ele, "há que se olhar isto como um fenômeno sociológico abrangente sem complexos de qualquer espécie". De acordo com seu olhar, as equipes de Portugal não são apenas clubes: "Fazem parte de uma herança cultural, tal como a língua portuguesa". ${ }^{98}$

De fato, segundo Darby, nas antigas colônias portuguesas na África pode-se perceber um relacionamento mais forte dos torcedores com os clubes de Portugal do que com os de cada país. ${ }^{99}$ Borges confirma esse fato em Cabo Verde, lembrando ainda outra curiosa ocorrência: agremiações locais que se apresentam como filiais de clubes da ex-metrópole (algo observável em todos os PALOPs). ${ }^{100} \mathrm{Na}$ verdade, Giulianotti e Robertson demonstram que o acompanhamento de campeonatos e times do continente europeu pode ser observado em muitos outros países africanos. Isso seria o desdobramento de uma estratégia comercial articulada entre equipes europeias e empresas transnacionais de comunicação. ${ }^{101}$

O importante, para concluir este artigo, é perceber o quanto a Taça

98 Disponível em: <http://cafemargoso.blogspot.com/2010/05/declaracao-cafeana_11.html>, acessado em 23/01/2013.

99 Paul Darby, "Migração para Portugal de jogadores de futebol africanos: recurso colonial e neocolonial", Análise Social, v.41, n.179 (2006), pp.417-33.

${ }^{100}$ Fernando Borges, "Pontapé inicial: um estudo de caso do futebol no Cabo Verde Moderno", in Victor Andrade de Melo, Marcelo Bittencourt e Augusto Nascimento (orgs.), Mais do que um jogo: o esporte no continente africano (Rio de Janeiro: Apicuri, 2010), pp.185-209.

${ }^{101}$ Richard Giulianotti e R. Robertson, Globalization and Football, Londres: Sage, 2009. 
Amílcar Cabral continuou sendo, durante muitos anos, a grande referência cabo-verdiana em matéria de competição internacional, ${ }^{102}$ a "nossa copa do mundo", como por vez ou outra a ela se referiu um jornalista.

É verdade que, para alguns, a comemoração da conquista em 2000, em certo sentido, fora "tumultuada" (ou ao menos minimizada) pela vitória, no mesmo dia, do Sporting no campeonato nacional da antiga metrópole. De qualquer forma, os "tubarões azuis" finalmente fizeram a bandeira do país tremular no mais alto patamar de um evento internacional.

No entanto, já não mais se tratava da mesma bandeira do período do PAIGC/PAICV. Com a adoção do multipartidarismo, e a vitória do Movimento Pela Democracia (MPD), os símbolos nacionais foram trocados, já não mais expressando claramente uma vinculação com o continente africano. Foram a nova bandeira e o novo hino os celebrados na conquista do torneio que levava, curiosamente, o nome daquele que tanto tentou alinhar Cabo Verde com a África: Amílcar Cabral.

Recebido em agosto de 2013 e aprovado em março de 2014.

${ }^{102}$ A Taça Amílcar Cabral foi disputada anualmente entre 1979 e 1989, passando a ser bienal até 1997. Depois de interrupção de três anos, foi retomada em 2000, 2001 e 2005. Retornaria em 2009, sendo adiada para 2010 e, por fim, cancelada. Senegal foi o país com mais títulos: oito. 


\title{
Resumo
}

Tendo em conta que é usual a mobilização da prática esportiva na construção de discursos identitários, este estudo tem por objetivo discutir as representações da imprensa de Cabo Verde sobre a participação da equipe nacional na Taça Amílcar Cabral, uma competição de futebol disputada, a partir de 1979, por seleções de países da chamada Zona 2 do Conselho Superior do Desporto da África. Trabalhou-se com o Voz di Povo, periódico dirigido pelo Partido Africano para Independência da Guiné e de Cabo Verde (PAIGC), que esteve à frente do governo entre os anos de 1975 e 1991. Sugerimos que as diferentes posições sobre o envolvimento do país com esse torneio nos permitem perceber as mudanças em curso na administração governamental, relacionadas, inclusive, aos trânsitos e negociações ligadas à identidade cabo-verdiana.

Palavras-chave: Cabo Verde - identidade - futebol - história do esporte.

\begin{abstract}
Considering the usual mobilizing of sport in the formation of identity discourses, this study aims to discussing the representations on local press about the participation of Cape Verde's national football team in Amilcar Cabral Cup. This tournament was established in 1979 and it includes the countries which belong to Zone 2 of The Supreme Council for Sport in Africa. We worked with Voz di Povo, directed by the African Party for the Independence of Guinea and Cape Verde (PAIGC), which ruled the country between 1975 and 1991. We suggest that the different points of view about the country's engagement in this tournament can let us perceive chances in the government administration of Cape Verde, related to the negotiations about cape-verdean identity.
\end{abstract}

Keywords: Cape Verde - identity - football - sport history. 